\title{
Studi Analisis Penggunaan TIK dalam Pembelajaran Fisika Terhadap Kesulitan Belajar
}

\author{
Halmuniati ${ }^{1}$, Zainuddin ${ }^{2}$, Jamarudin ${ }^{3}$ \\ ${ }^{1}$ FakultasTarbiyah dan Ilmu Keguruan IAIN Kendari \\ Email: halmuniati88@gmail.com \\ ${ }^{2}$ FakultasTarbiyah dan Ilmu Keguruan IAIN Kendari \\ Email: zainuddin.fisika11@gmail.com \\ ${ }^{3}$ Tadris Fisika FakultasTarbiyah dan Ilmu Keguruan IAIN Kendari \\ Email: jamarudinfsk@gmail.com
}

\begin{abstract}
Abstrak
Artikel ini bertujuan untuk mengetahui perbedaan pembelajaran fisika dengan menggunakan teknologi informasi dan komunikasi terhadap kesulitan belajar siswa di sekolah menengah atas yang ada di Kecamatan Parigi Kabupaten Muna. Penelitian ini menggunakan pendekatan kuantitatif dengan metode kuasi eksperimen menggunakan posttes.Populasi dalam penelitian ini adalah seluruh siswa kelas XI dan guru yang ada di SMAN 1 Parigi dan SMAN 2 Parigi Kabupaten Muna.Teknik penarikan sampel menggunakan purposive sampling dimana semua siswa Kelas XI IPA digunakan sebagai sampel yang terdiri dari 2 orang guru fisika dan 99 siswa dari kedua sekolah tersebut.Teknik analisis data untuk menjawab permasalahan pada hipotesis penelitian ini adalah analis SPSS 19. Hasil analisis data menunjukan bahwa Pembelajaran fisika dengan menggunakan teknologi informasi dan komunikasi (TIK) memiliki pengaruh terhadap kesulitan belajar siswa SMAN 1 Parigi yang terlihat pada analisis uji ANOVA yaitu nilai $\mathrm{F}$ hitung $=>\mathrm{F}$ tabel untuk semua variable kelas yang di uji. Dengan hasil ini menunjukkan bahwa ada perbedaan penggunaan teknologi informasi dan komunikasi terhadap kesulitan belajar fisika siswa.
\end{abstract}

\section{Kata kunci: Penggunaan TIK, Kesulitan belajar, SMAN 1 Parigi, SMAN 2 Parigi}




\title{
Study of Analysis Use ICT in Physical Learning on the Difficulty Learning
}

\author{
Halmuniati ${ }^{1}$, Zainuddin ${ }^{2}$, Jamarudin ${ }^{3}$ \\ ${ }^{1}$ FakultasTarbiyah dan Ilmu Keguruan IAIN Kendari \\ Email: halmuniati88@gmail.com \\ ${ }^{2}$ FakultasTarbiyah dan Ilmu Keguruan IAIN Kendari \\ Email: zainuddin.fisika11@gmail.com \\ ${ }^{3}$ Tadris Fisika FakultasTarbiyah dan Ilmu Keguruan IAIN Kendari \\ Email: jamarudinfsk@gmail.com
}

\begin{abstract}
This study aims to know the difference in physics learning by using information and communication technology to the learning difficulties of students in high schools in Parigi District, Muna Regency. This research uses a quantitative approach with a quasiexperimental method using posttes. The population in this study were all students of class XI and teachers in SMAN 1 Parigi and SMAN 2 Parigi Muna Regency. The sampling technique used purposive sampling where all students of Class XI Science were used as a sample consisting of 2 physics teachers and 99 students from the two schools. The data analysis technique to answer the problem in this research hypothesis is SPSS 19 analyst. The results of the data analysis show that physics learning using information and communication technology (ICT) has an influence on the learning difficulties of Parigi 1 High School students as seen in the ANOVA test analysis, namely the calculated $F$ value $=>F$ table for all class variables tested. With these results it shows that there are differences in the use of information and communication technology on students' physics learning difficulties.
\end{abstract}

Keywords: Use ICT, Learning Difficulties, SMAN 1 Parigi, SMAN 2 Parigi 


\section{Pendahuluan}

Pendidikan merupakan sebuahsaran penting baik untuk sosial, teknologi maupun bangsa yang secara ilmiah untuk memenuhi standarhidup yang dikaitkan secara global ${ }^{1}$.Selain itu menjadi jalan untuk pelatihan dan pembelajaran, terutama di sekolah sertadi perguruan tinggi, untuk menambah pengetahuan danmengembangkan keterampilan, yang mana tujuan akhir dari sebuah sistem pendidikan adalah untuk memberdayakan seseorang untuk unggul dalam bidang usaha yang dipilihatau karir, dan dapat berdampak positif terhadap lingkungannya ${ }^{2}$.

Perkembangan ilmu pengetahuan dan teknologi (IPTEK) yang begitu pesat, memberikan dampak pada berbagai aspek kehidupan manusia termasuk dalam bidang pendidikan, yang mana di dalamnya terdapat suatu proses akademik yang bertujuan untuk meningkatkan nilai sosial, budaya, moral dan agama serta mempersiapkan peserta didik menghadapi tantangan dan pengalaman dalam kehidupan nyata ${ }^{3}$. Fisika merupakandasar dalam memahami kompleksitas teknologi modern yang penting untuk kemajuan teknologi suatu bangsa. Aspek sains ini mampu memberikan sumbangsihyang signifikan bagi banyak penemuan di zaman modern dan telah membantu menjelaskan banyak peristiwa yang ditemui dalam lingkungan seperti. Akan tetapi lebih dari satu dekade ini, di banyak negara barat termasuk kawasan Asia Tenggara khususnya di Indonesia, minat karir di bidang sains dan teknologi menurun ${ }^{4}$.Fisika masih dianggap sulit oleh sebagaian besar siswa.Teknologi Informasi dan Komunikasi (TIK) memiliki manfaat yang begitu luas terhadap pencapaian tujuan pendidikan. Melalui TIK, guru dan peserta didik dapat mengoptimalkan potensipendidikan yang ada sehingga tujuan pendidikan yang telah direncanakan bisa segera tercapai.

\footnotetext{
${ }^{1}$ Joseph, Endurance,A.,\& Okere, I. (2015).Academic Achievement of Students in Basic Science among Secondary Schools in Rivers State: Synergy of Parents" Educational Background, Socio- Economic Status and School Location. International Journal of Science and Research (IJSR).

${ }^{2}$ Assefa, B., et al. (2008). Action Research on Enhancing Academic Excellence in a Study Program.Ethiopian Journal of Education and Sciences.

${ }^{3}$ Munir.(2012). Pembelajaran Jarak jauh Berbasis Teknologi Informasi dan Komunikasi, Bandung: Alfabeta.

${ }^{4}$ OECD.(2014). Perancis.
} 
Selain Teknologi Informasi dan Komunikasi (TIK) telah memberikan pengaruh terhadap dunia pendidikan khususnya dalam proses pembelajaran. Dengan berkembangnya penggunaan TIK ada lima pergeseran dalam proses pembelajaran yaitu: (1) dari pelatihan ke penampilan, (2) dari ruang kelas ke di mana dan kapan saja, (3) dari kertas ke "on line" atau saluran, (4) fasilitas fisik ke fasilitas jaringan kerja, (5) dari waktu siklus ke waktu nyata. Namun demikian, dalam kenyataanya pembelajaran TIK di sekolah, masih "jauh panggang dari api”. Pembelajaran TIK, sering disederhanakan hanya sebagai latihan penggunaan komputer. Inilah yang disebut sebagai masih adanya persoalan sistemik dan operasional tentang kebijakan kurikulum dihubungkan dengan derajat implementasi kurikulum di tingkat sekolah, termasuk dalam pembelajaran TIK.

Zahra dan Ali Habibi dalam penelitiannya diperoleh bahwa pemanfaatan TIK dalam pembelajaran fisika sangat memiliki pengaruh yang signifikan terhadap pembelajaran fisika. Dimana konsep-konsep fisika yang dianggap sulit dijelaskan secara manual dengan menggunakan powerpoint, video animasi bisa membuat siswa lebih mengerti tentang fisika ${ }^{5}$. Hal serupa juga dilakukan oleh Khalid dkk di Pakistan menemukan bahwa meskipun penggunaan TIK tidak sepenuhnya menjamin kualiatas pendidikan lebih baik tetapi khusus untuk pembelajaran fisika penggunaan TIK dapat memberikan kontribusi nyata dalam penjelasan konsep.Hampir semua guru disana setuju dengan penggunaan TIK dan mengaplikasikan dalam pembelajaran untuk memudahkan mereka mengajar ${ }^{6}$.

Kesulitan belajar merupakan gejala yang terjadi dalam suatu proses belajar yang ditandai dengan adanya berbagai tingkah laku yang muncul baik dari dalam diri siswa maupun dari luar ${ }^{7}$. Sepertipenelitian di Nigeria terhadap pengaplikasian TIK dalam pembelajaran diperoleh hampir seluruh sekolah yang menjadi objek

${ }^{5}$ Zahra, H., \& Ali, H. (2014).The Effect Of Information Technology in Teaching Physics Courses. The Eurasia Proceedings of Educational \& Social Sciences (EPESS).Volume 1, 391-396.

${ }^{6}$ Khalid, K., Ahmad, F.S., \& Norman, R. (2016).Information and Communication Technology in Learning Physics at Secondary School Level in Pakistan. Bulletin of Education and Research, Vol. 38, No. 2, 135-151.

Dalam Belajar.

${ }^{7}$ Zakir, S. 2007. Usaha Guru Dalam Mengatasi Anak Yang Bermasalah 
penelitian sudah memiliki fasilitas TIK seperti komputer. Akan tetapi dorongan untuk penerapannya didalam proses pembelajaran masih mengalami berbagai hambatan. Hambatan tersebut terjadi dikarenakan guru masih agak kurang terampil dalam mengoperasikan komputer sehingga berpengaruh terhadap minat belajar siswa.Akibatnya siswa mengalami kesulitan dalam memahami pembelajaran fisika yang diajarkan dengan menggunakan pembelajaran manual dan monoton ${ }^{8}$.

Sekolah Menengah Atas Negeri 1 Parigi merupakan 1 dari 2 Sekolah Menengah Atas yang ada di Kecamatan Parigi Kabupaten Muna.Sekolah ini dibangun pada tahun 2006 letaknya agak jauh dari poros. Kondisi dari sekolah ini dari dulu hingga sekarang masih tetap seperti itu, dimana sarana dan prasarana yang ada disekolah ini belum memadai seperti sekolah lain. Dari observasi awal di sekolah diperoleh sebagian besar guru yang ada di sekolah tersebut termasuk fisika dalam mengajar tidak menggunakan media atau komputer.Mereka kebanyakan masih menggunakan pembelajaran yang manual dengan motode pembelajaran yang masih tradisional. Dari wawancara singkat dengan seorang guru fisika di SMAN 1 Parigi, salah satu penyebab tidak dilaksanakannya pembelajaran menggunakan Teknologi Informasi dan Komunikasi karena kondisi sekolah tidak mendukung dari segi sarana dan prasarana. Dalam kondisi seperti ini guru hanya bisa mengajarkan fisika secara manual saja. Hasilnya banyak siswa kesulitan dalam pemahaman materi fisika sehingga menganggap fisika itu sangat sulit dipahami dibanding mata pelajaran yang lain ${ }^{9}$.

Hal serupa juga terjadi di Sekolah Menengah Atas negeri 2 Parigi yang letaknya didekat jalan poros Walambenowite.Sekolah ini pun berdiri pada tahun 2006 hampir bersamaan dengan SMAN 1 Parigi. Disekolah ini untuk sarana dan prasarana sedikit memadai akan tetapi guru masih tetap tidak bisa menggunakan media TIK dalam proses pembelajaran dikarenakan infocus yang ada di sekolah tersebut hanya 1. Dari wawacara bersama guru fisika ditemukan bahwa siswa masih sangat kesulitan dalam memahami kosep fisika.Hal ini

${ }^{8}$ Israel, O.O., Chetta, W.,\& Lebe, A.N. (2014). Information and Communication Technology (ICT) Support Systems for Teaching and Learning Physics in Selected Secondary Schools in Eleme Local Government Area. 4(4): 7987.

\footnotetext{
${ }^{9}$ Murniati.(2019). Guru fisika SMAN 1 Parigi.
} 
dikarenakan tidak adanya media yang bisa digunakan oleh guru dalam mengajar. ${ }^{10}$

Banyak faktor yang berpengaruh atau mendukung terwujudnya proses pembelajaran yang berkualitas dalam upaya mencapai tujuan pendidikan, salah satu di antaranya adalah penggunaan atau pemanfaatan teknologi dalam proses pendidikan dan pembelajaran. Teknologi pembelajaran yang dewasa ini aplikasinya berupa pemanfaatan proses dan produk teknologi informasi dan komunikasi (information and communication technology/ICT) untuk memecahkan masalah-masalah pendidikan dan pembelajaran, memiliki banyak manfaat atau keuntungan Dari beberapa kasus tersebut, maka penelitian ini sangat penting dilakukan untuk menganalisis apakah penggunaan Teknologi Informasi dan Komunikasi dalam pembelajaran fisika dapat mengatasi kesulitan belajar siswa yang ada di Sekolah Menengah Atas se Kecamatan Parigi Kabupaten Muna.

Teknologi adalah sebuah proses yang dilaksanakan dalam upaya mewujudkan sesuatu secara rasional. Vaza menekankan kata rasional dalam pengertian teknologi tersebut. Saat ini perkembangan teknologi informasi (TI) telah memberikan pengaruh terhadap dunia pendidikan khususnya dalam proses pembelajaran. Menurut Rosenberg, dengan berkembangnya penggunaan TI ada lima pergeseran dalam proses pembelajaran yaitu: (1) dari pelatihan ke penampilan, (2) dari ruang kelas ke di mana dan kapan saja, (3) dari kertas ke "on line" atau saluran, (4) fasilitas fisik ke fasilitas jaringan kerja, dan (5) dari waktu siklus ke waktu nyata. ${ }^{11}$

Pentingnya pemanfaatan TIK dalam pembelajaran mengingat potensi TIK itu sendiri dalam memfasilitasi dan mengoptimalkan proses belajar siswa antara lain: 1) membuat konkrit konsep yang abstrak, misalnya untuk menjelaskan sistem peredaran darah; 2) membawa obyek yang berbahaya atau sukar didapat ke dalam lingkungan belajar, seperti: binatang-binatang buas, atau penguin dari kutub selatan; 3) menampilkan obyek yang terlalu besar, seperti pasar, candi borobudur; 4) menampilkan obyek yang tidak dapat dilihat

${ }^{10}$ Laode, A. (2019). Guru Fisika SMAN 2 Parigi.

${ }^{11}$ Yusri.(2015). Pengaruh Penggunaan Media Teknologi Informasi dan Komunikasi (TIK) dengan Prestasi Belajar Bahasa Inggris Peserta Didik Kelas X di SMAN I Dekai Kabupaten Yahukimo.Jurnal Ilmiah ILKOM, Vol. 8 No. 1, 51. 
dengan mata telanjang, seperti: mikro organisme; 5) mengamati gerakan yang terlalu cepat, misalnya dengan slow motion atautimelapse photograhy; 6) memungkinkan siswa berinteraksi langsung dengan lingkungannya; 7) memungkinkan keseragaman pengamatan dan persepsi bagi pengalaman belajar siswa; 8) membangkitkan motivasi belajar siswa; 9) menyajikan informasi belajar secara konsisten, akurat, berkualitas dan dapat diulang penggunaannya atau disimpan sesuai dengan kebutuhan; 10) menyajikan pesan belajar secara serempak untuk lingkup sasaran yang sedikit/kecil atau banyak/luas, mengatasi batasan waktu (kapan saja) maupun ruang di mana saja).

Fisika merupakan salah satu cabang dari IPA dan merupakan ilmu yang lahir dan berkembang lewat langkah-langkah ilmiah, mulai dari perumusan masalah, penyusunan hipotesis, pengujian hipotesis melalui eksperimen, penarikan kesimpulan, serta penemuan teori dan konsep.Mempelajari fisika merupakan suatu petualangan. Anda akan menemukan bahwa ilmu ini begitu menantang, kadang-kadang membuat frustasi, sewaktu-waktu menyakitkan, dan seringkali bermanfaat dan memberikan kepuasan batin. Fisika akan menarik rasa estetis seperti halnya intelektualitas anda ${ }^{12}$.

Kesulitan belajar adalah beragam bentuk kesulitan yang nyata dalam aktivitas mendengarkan, bercakap-cakap, membaca, menulis, menalar, dan berhitung.Gangguan tersebut berupa gangguan intrinsik yang diduga karena adanya disfungsi sistem saraf pusat ${ }^{13}$. Kesulitan belajar pada intinya merupakan sebuah permasalahan yang menyebabkan seorang siswa tidak dapat mengikuti proses pembelajaran dengan baik seperti siswa lain pada umumnya yang disebabkan oleh faktor-faktor tertentu sehingga ia terlambat atau bahkan tidak dapat mencapai tujuan belajar yang diharapkan. Seorang siswa dapat diduga mengalami kesulitan belajar bila peserta didik yang bersangkutan menunjukkan kegagalan atau tidak dapat mencapai tujuan belajar yang ditetapkan.Di antara kegagalan tersebut adalah jika dalam waktu yang telah ditentukan peserta didik tidak dapat

${ }^{12}$ Abbas, M.Y.H. (2018).Faktor-Faktor Kesulitan Belajar Fisika Pada Peserta Didik Kelas IPA Sekolah Menengah Atas. Jurnal Pendidikan Fisika.

${ }^{13}$ Nini, S. (2011). Mengatasi Kesulitan Belajar Pada Anak, Jogjkarta: Javalitera, 12. 
mencapai kriteria minimal penguasaan materi yang telah ditetapkan oleh guru $^{14}$.

Ahmadi dan Supriyono, menyebutkan bahwa terdapat beberapa macam kesulitan belajar pada siswa sebagai berikut: 1) Dilihat dari jenis kesulitannya, kesulitan belajar dikelompokkan menjadi kesulitan belajar ringan, sedang dan berat. 2) Dilihat dari jenis bidang studi yang dipelajarinya, kesulitan belajar pada siswa dapat berupa kesulitan belajar pada sebagian kecil maupun sebagian besar bidang studi. 3) Dilihat dari sifat kesulitan belajarnya, kesulitan belajar pada siswa dapat berupa kesulitan belajar yang sifatnya menetap dan kesulitan belajar yang sifatnya sementara. 4) Dilihat dari fokus penyebabnya, belajar pada siswa dapat berupa kesulitan belajar karena faktor inteligensia dan kesulitan belajar karena faktor noninteligensia ${ }^{15}$.

Secara garis besar faktor kesulitan belajar terdiri atas dua macam, yakni factor intern siswa adalah hal-hal atau keadaan-keadaan yang muncul dari dalam diri siswa sendiri dan factor ekstern siswa adalah hal-hal atau keadaan yang dating dari luar diri siswa, dari kedua factor ini meliputi aneka ragam hal dan keadaan yaitu sebagai berikut: 1) Factor Intern Siswa. Faktor intern siswa meliputi gangguan atau kekurangmampuan psikofisik siswa, yaitu terdiri dari tiga hal pertama yang bersifat kognitif (ranah cipta) antara lain rendahnya kapasitas intelektual/inteligensi siswa. Kedua, yang bersifat afektif (ranah rasa) antara lain seperti labilnya emosi dan sikap. Ketiga, yang bersifat psikomotorik (ranah karsa) antara lain seperti terganggunya alat-alat indera penglihatan dan pendengar (mata dan telinga). 2) Factor Ekstern Siswa.Semntara faktor ekternal meliputi: a) Lingkungan Keluarga seperti broken home, rendah kehidupan ekonomi. Pengaruh keluarga yang tidak harmonis yang mempengaruhi perkembangan mental seseorang.Apalagi jika berada dalam lingkungan keluarga yang memiliki kehidupan ekonomi yang paspasan atau bahkan berkekurangan.Hal ini dapat berdampak bagi melemahnya kemampuan seseorang dalam menyerap materi pelajaran yang semestinya dikuasai.b) Lingkungan Masyarakat seperti perkampungan kumuh, teman sepermainan yang nakal. Lingkungan

\footnotetext{
${ }^{14}$ Mohammad, I., \& Novan, A.W. (2013).Psikologi Pendidikan Teori dan Aplikasi dalam Proses Pembelajaran.Jogjakarta: Ar-ruz Media, 253-254.

${ }^{15}$ Mohammad, I., \& Novan, A.W. Ibid.
} 
rumah yang terletak di area yang kumuh, jauh dari ketenangan dan ketentraman tentu akan memberi dampak bagi perkembangan, mental seseorang. Biasanya pengaruh yang ditimbulkan adalah bersifat negatif, perokok yang menjadi pecandu narkotika, mabuk-mabukan , serta segala keterbatasan sarana yang dapat menstimulasi seseorang berkembang secara negative. c) Lingkungan sekolah seperti Kondisi dan letak gedung sekolah buruk, misalnya dekat pasar, kondisi gurun atau alat-alat belajar yang berkualitas rendah. Lingkungan sekolah yang kurang mendukung saran belajar dapat mengacaukan konsentrasi belajar sebab berdampak pada penurunan kemampuan prestasi tinggi.Sangat jarang ditemukan siswa yang maju berasal dari lingkungan sekolah yang kurang kondusif. Oleh karena itu, suasana yang nyaman tanpa keributan, serta fasilitas belajar yang memadai, akan mendorong lahirnya siswa-siswi yang berprestasi tinggi. ${ }^{16}$

\section{Metode}

Pendekatan dalam penelitian ini menggunakan pendekatan penelitian kuantitatif.Jenis penelitian yang digunakan yaitu eksperimen kuasi atau Quasi Experimental Design.Quasi Experiment Design atau eksperimen semu yaitu penelitian yang dilaksanakan tanpa adanya kelas pembanding atau kelas kontrol ${ }^{17}$.Penelitian ini dilaksanakan di 2 sekolah yang ada di Kecamatan Parigi Kabupaten Muna yaitu SMAN 1 Parigi dan SMAN 2 Parigi. Desain penelitian yang digunakan dalam penelitian ini adalah Quasi Experiment dengan one group pretest and posttest design. teknik pengumpulan data yang digunakan dalam penelitian ini adalah: 1) Teknik observasi yang dilakukan menggunakan observasi tidak terstruktur; 2) Teknik wawancara yang dilakukan tidak terstruktur untuk menggali informasi; 3) Teknik Tes menggunakan soal post test. Metode analisis data yang digunakan dalam penelitian ini yaitu analisis deskriptif dan analisis statistik inferensial yaitu dengan menggunakan Sofware SPSS dan Microsoft excel.

\footnotetext{
${ }^{16}$ Abbas, M.Y.H.Ibid.

${ }^{17}$ Arikunto, S. (2012). Prosedur Penelitian Suatu Pendekatan Praktik. Jakarta: Rineka Cipta.
} 


\section{Hasil Penelitian}

Analisis Deskripsi Data Variabel Penelitian SMAN 1 Parigi

Descriptive Statistics

\begin{tabular}{|l|l|r|r|r|r|}
\hline & $\mathrm{N}$ & Minimum & Maximum & Mean & $\begin{array}{c}\text { Std. } \\
\text { Deviation }\end{array}$ \\
\hline PREEXI.MIA1 & 25 & 20.00 & 64.00 & 42.4000 & 9.01850 \\
POSTXI.MIA1 & 25 & 64.00 & 96.00 & 80.1600 & 8.36501 \\
PREEXI.MIA2 & 25 & 20.00 & 52.00 & 39.0400 & 8.81514 \\
POSTXI.MIA2 & 25 & 68.00 & 96.00 & 81.4400 & 8.93532 \\
Valid N & 25 & & & & \\
(listwise) & & & & & \\
\hline
\end{tabular}

Dari output pengolahan data dapat dilihat untuk semua kelas jumlah data adalah sama yaitu 25 Siswa dengan nilai minimum untuk pretes kelas XI MIA 1 sebesar 20, nilai maksimum sebesar 64, nilai rata-rata sebesar 42 dengan nilai standar deviasi sebesar 9,02. Nilai posttes XI MIA 1 minimum 64, nilai maksimum sebesar 96 dengan nilai rata-rata sebesar 80 dan standar deviasi sebesar 8,36 . Selanjutnya nilai pretes pada Kelas XI MIA 2 nilai minimum sebesar 20, nilai maksimum 52, nilai rata-rata sebesar 39 dengan nilai standar deviasi sebesar 8,81. Nilai posttes XI MIA 2 minimum 68, nilai maksimum sebesar 96 dengan nilai rata-rata sebesar 81 dan standar deviasi sebesar 8,93.

Analisis Deskripsi Data Variabel Penelitian SMAN 2 Parigi Descriptive Statistics

\begin{tabular}{|l|l|r|r|c|r|}
\hline & $\mathrm{N}$ & Minimum & Maximum & Mean & $\begin{array}{c}\text { Std. } \\
\text { Deviation }\end{array}$ \\
\hline PREEXI.IPAA & 25 & 25.00 & 58.00 & 41.2000 & 10.63798 \\
POSTXI.IPAA & 25 & 57.00 & 92.00 & 76.3600 & 10.11962 \\
PREEXI.IPAB & 24 & 25.00 & 58.00 & 38.7917 & 9.77565 \\
POSTXI.IPAB & 24 & 67.00 & 92.00 & 79.5000 & 8.50575 \\
Valid N & 24 & & & & \\
(listwise) & & & & & \\
\hline
\end{tabular}


Dari output pengolahan data diatas, dapat dilihat untuk kelas XI IPA A jumlah data adalah25 Siswa sedangkan kelas XI IPA B jumlah data adalah 24 siswa dengan nilai minimum untuk pretes kelas XI IPA A sebesar 25, nilai maksimum sebesar 58, nilai rata-rata sebesar 41 dengan nilai standar deviasi sebesar 10.64. Nilai posttes XI IPA A minimum 57, nilai maksimum sebesar 92 dengan nilai rata-rata sebesar 76 dan standar deviasi sebesar 10.12. Selanjutnya nilai pretes pada Kelas XI IPA B nilai minimum sebesar 25, nilai maksimum 58, nilai rata-rata sebesar 39 dengan nilai standar deviasi sebesar 9.77. Nilai posttes XI MIA 2 minimum 67, nilai maksimum sebesar 92 dengan nilai rata-rata sebesar 79 dan standar deviasi sebesar 8,51.

\section{Uji Normalitas data SMAN 1 Parigi}

One-Sample Kolmogorov-Smirnov Test

\begin{tabular}{|c|c|c|c|c|c|c|c|}
\hline & & $\begin{array}{l}\text { PREEX } \\
\text { I.MIA1 }\end{array}$ & $\begin{array}{l}\text { POSTX } \\
\text { I.MIA1 }\end{array}$ & $\begin{array}{l}\text { PREEX } \\
\text { I.MIA2 }\end{array}$ & $\begin{array}{l}\text { POSTX } \\
\text { I.MIA2 }\end{array}$ & $\begin{array}{c}\text { GAIN } \\
\text { XIMI } \\
\text { A1 }\end{array}$ & $\begin{array}{l}\text { GAINX } \\
\text { I.MIA2 }\end{array}$ \\
\hline \multicolumn{2}{|l|}{$\mathrm{N}$} & 25 & 25 & 25 & 25 & 25 & 25 \\
\hline \multirow{2}{*}{$\begin{array}{l}\text { Normal } \\
\text { Parameters }\end{array}$} & Mean & 42.400 & 80.1600 & 39.0400 & 81.4400 & .6472 & .6896 \\
\hline & $\begin{array}{l}\text { Std. } \\
\text { Deviation }\end{array}$ & 9.0185 & 8.36501 & 8.81514 & 8.93532 & .1548 & .16501 \\
\hline \multirow{3}{*}{$\begin{array}{l}\text { Most } \\
\text { Extreme } \\
\text { Differences }\end{array}$} & Absolute & .125 & .149 & .153 & .135 & .116 & .109 \\
\hline & Positive & .125 & .131 & .108 & .135 & .116 & .073 \\
\hline & Negative & -.119 & -.149 & -.153 & -.133 & -.078 & -.109 \\
\hline \multicolumn{2}{|c|}{ Kolmogorov-Smirnov Z } & .625 & .747 & .766 & .673 & .578 & .546 \\
\hline \multicolumn{2}{|c|}{ Asymp. Sig. (2-tailed) } & .830 & .632 & .601 & .755 & .892 & .927 \\
\hline
\end{tabular}

a. Test distribution is Normal.

b. Calculated from data.

Dari output terlihat bahwa semua data terdistribusi dengan normal. Ini terlihat dari nilai (Asymp Sig 2-tailed) >0,05.

\section{Uji Normalitas SMAN 2 Parigi}

One-Sample Kolmogorov-Smirnov Test

\begin{tabular}{|l|r|r|r|r|r|r|}
\hline & $\begin{array}{c}\text { PREEX } \\
\text { I.IPAA }\end{array}$ & $\begin{array}{c}\text { POSTX } \\
\text { I.IPAA }\end{array}$ & $\begin{array}{c}\text { PREE } \\
\text { XIIPA } \\
\text { B }\end{array}$ & $\begin{array}{c}\text { POSTX } \\
\text { I.IPAB }\end{array}$ & $\begin{array}{c}\text { GAIN } \\
\text { XIIPA } \\
\text { A }\end{array}$ & $\begin{array}{c}\text { GAIN } \\
\text { XI.IPA } \\
\text { B }\end{array}$ \\
\hline $\mathrm{N}$ & 25 & 25 & 24 & 24 & 25 & 24 \\
\hline
\end{tabular}




\begin{tabular}{|ll|r|r|r|r|r|r|} 
Normal & Mean & 41.200 & 76.3600 & 38.79 & 79.5000 & .5868 & .6646 \\
$\mathrm{~s}^{\mathrm{a}, \mathrm{b}}$ & 0 & & 1 & & & \\
& Std. & 10.637 & 10.1196 & 9.775 & 8.50575 & .2020 & .1373 \\
& & & & & \\
Most & Absolute & .260 & .223 & .265 & .202 & .145 & .109 \\
Extreme & Positive & .260 & .223 & .265 & .202 & .089 & .097 \\
Differences & Negative & -.156 & -.184 & -.152 & -.160 & -.145 & -.109 \\
Kolmogorov-Smirnov & 1.298 & 1.113 & 1.298 & .988 & .723 & .534 \\
Z & & & & & & \\
Asymp. Sig. (2-tailed) & .069 & .168 & .069 & .283 & .672 & .938
\end{tabular}

a. Test distribution is Normal.

b. Calculated from data.

Uji Hipotesis SMAN 1 Parigi Kelas XI MIA 1

\section{ANOVA}

NILAI

\begin{tabular}{|l|r|r|r|r|r|}
\hline & \multicolumn{1}{|c|}{$\begin{array}{c}\text { Sum of } \\
\text { Squares }\end{array}$} & df & Mean Square & F & Sig. \\
\hline Between & 17822.720 & 1 & 17822.720 & 235.58 & .000 \\
Groups & 3631.360 & 48 & 75.653 & & \\
Within Groups & 21454.080 & 49 & & & \\
Total & & & & \\
\hline
\end{tabular}

Dari tabelterlihat bahwa nilai sig $<0,05$ maka ada perbedaan penggunaan teknologi informasi dan komunikasi terhadap kesulitan belajar fisika kelas XI MIA 1.

\section{Uji Hipotesis SMAN 1 Parigi Kelas XI MIA 2}

ANOVA

\begin{tabular}{|l|r|r|r|r|r|}
\hline & \multicolumn{1}{|c|}{ NILAI2 2 Squares } & df & Mean Square & F & Sig. \\
\hline Between Groups & 22472.000 & 1 & 22472.000 & 285.274 & .000 \\
Within Groups & 3781.120 & 48 & 78.773 & & \\
Total & 26253.120 & 49 & & & \\
\hline
\end{tabular}


Dari table terlihat bahwa nilai sig $<0,05$ maka ada perbedaan penggunaan teknologi informasi dan komunikasi terhadap kesulitan belajar fisika kelas XI MIA 2.

\section{Uji Hipotesis SMAN 2 Parigi Kelas XI IPA A} ANOVA

NILAI3

\begin{tabular}{|c|c|c|c|c|c|}
\hline & $\begin{array}{l}\text { Sum of } \\
\text { Squares }\end{array}$ & df & $\begin{array}{l}\text { Mean } \\
\text { Square }\end{array}$ & $\mathrm{F}$ & Sig. \\
\hline $\begin{array}{l}\text { Between } \\
\text { Groups } \\
\text { Within } \\
\text { Groups } \\
\text { Total }\end{array}$ & $\begin{array}{r}15452.820 \\
5173.760 \\
20626.580\end{array}$ & $\begin{array}{l}48 \\
49\end{array}$ & $\begin{array}{r}15452.820 \\
107.787\end{array}$ & 143.36 & .000 \\
\hline
\end{tabular}

Dari table terlihat bahwa nilai sig $<0,05$ maka ada perbedaan penggunaan teknologi informasi dan komunikasi terhadap kesulitan belajar fisika kelas XI IPA A.

\section{Uji Hipotesis SMAN 2 Parigi Kelas XI IPA B} ANOVA

NILAI4

\begin{tabular}{|c|c|c|c|c|c|}
\hline & $\begin{array}{c}\text { Sum of } \\
\text { Squares }\end{array}$ & df & $\begin{array}{c}\text { Mean } \\
\text { Square }\end{array}$ & F & Sig. \\
\hline Between & 19886.021 & 1 & 19886.021 & 236.86 & .000 \\
Groups & 3861.958 & 46 & 83.956 & 3 & \\
$\begin{array}{c}\text { Within } \\
\text { Groups } \\
\text { Total }\end{array}$ & 23747.979 & 47 & & & \\
\hline
\end{tabular}

Dari table terlihat bahwa nilai sig $<0,05$ maka ada perbedaan penggunaan teknologi informasi dan komunikasi terhadap kesulitan belajar fisika kelas XI IPA B.

\section{Pembahasan}

Penggunaan TIK dalam dunia pendidikan dapat meningkatkan kualitas dari proses pembelajaran karena dapat meningkatkan motivasi belajar dan keaktifan siswadalam pembelajaran. TIK bisa dijadikan sebagai media atau alat yang lebih berpusat pada siswa.Selain itu penggunaan TIK ini dapat membantu siswa dalam mengatasi kesulitan 
belajar fisika yang mayoritas disekolah menengah yang terdapat di Kecamatan Parigi kesulitan dalam memahami konsep fisika.

Dari hasil penelitian yang dilakukandi SMAN 1 Parigi diperoleh bahwasanya terdapat perbedaan yang cukup signifikan sebelum dan sesudah penggunaan TIK terhadap kesulitan belajar fisika siswa. Hal ini terlihat dari kurangnya pemahaman konsep fisika siswa dalam memahami setiap materi yag diajakan oleh guru yang masih menggunakan metode tradisioal dalam proses belajar mengajar tanpa dilengkapi media atau alat perangga. Sehingga menyebabkan siswa kurang bersemangat dalam mengikuti pelajaran fisika atau kurang termotivasi sehingga mereka menanamkan bahwa fisika itu sult dan hanya dengan hafalan.Akan tetapi ini berbanding terbalik manakala siswa diajar dengan menggunakan media TIK dalam hal ini menggunakan Powerpointdan video dengan bantuan Infocus. Sehingga ketika mengikuti kegiatan belajar mengajar siswa jadi bersemangat dan lebih banyak bertanya tentang banyak hal dalam setiap video yang ditampilkan.Ini disebabkan karena siswa disekolah ini baru pertama kali melihat Infocusatau media pembelajaran seperti itu.

Hal yang sama juga terjadi di SMAN 2 Parigi. Di sekolah ini jua sama sekali tidak menggunakan media belajar. Tidak adanya penggunaan media disekolah ini disebabkan oleh kurangnya sarana dan prasarana yang ada disekolah ini sehingga guru kesulitan untuk menerapkan media belajar baik itu alat peraga ataupun media komputer.Dengan kondisi tersebut guru kesusahan dalam menajarkan konsep fisika.Kesulitan belajar ini disebabkan oleh banyak factor, salah satunya adalah lingkungan sekolah seperti Kondisi dan letak gedung sekolah buruk, misalnya dekat pasar, kondisi gurun atau alatalat belajar yang berkualitas rendah.Lingkungan sekolah yang kurang mendukung saran belajar dapat mengacaukan konsentrasi belajar sebab berdampak pada penurunan kemampuan prestasi tinggi.Sangat jarang ditemukan siswa yang maju berasal dari lingkungan sekolah yang kurang kondusif. Oleh karena itu, suasana yang nyaman tanpa keributan, serta fasilitas belajar yang memadai, akan mendorong lahirnya siswa-siswi yang berprestasi tinggi.

\section{Kesimpulan dan Saran}

Hasil-hasil temuan penelitian mengenai penggunaan teknologi informasi dan komunikasi terhadap kesulitan belajar fisika siswa menunjukan bahwa persepsi guru fisika di SMAN 1 Parigi dan SMAN 
2 Parigi yang ada di Kecamatan Parigi terhadap penggunaan media TIK dalam proses pembelajaran yaitu guru belum menggunakan teknologi informasi dan komunikasi dalam proses pembelajaran, sehingga mengakibatkan adanya perbedaan penggunaan teknologi informasi dan komunikasi terhadap kesulitan belajar fisika.Hal ini disebabkan karena kurangnya sarana dan prasarana yang ada disekolah tersebut.

Sebagai implikasi dari penelitian ini, penulis menyarankan kepada pihak sekolah untuk memperbaiki dan meningkatkan sarana dan prasarana sekolah agar guru tidak kesulitan dalam menghadirkan media pembelajaran dalam proses belajar mengajar.

\section{Daftar Pustaka}

Abbas, M.Y.H. (2018). Faktor-Faktor Kesulitan Belajar Fisika Pada Peserta Didik Kelas IPA Sekolah Menengah Atas. Jurnal Pendidikan Fisika.

Arikunto, S. (2012). Prosedur Penelitian Suatu Pendekatan Praktik. Jakarta: Rineka Cipta.

Assefa, B., et al. (2008). Action Research on Enhancing Academic Excellence in a Study Program.Ethiopian Journal of Education and Sciences.

Israel, O.O., Chetta, W.,\& Lebe, A.N. (2014). Information and Communication Technology (ICT) Support Systems for Teaching and Learning Physics in Selected Secondary Schools in Eleme Local Government Area. 4(4): 79-87.

Joseph, Endurance, A., \& Okere, I. (2015).Academic Achievement of Students in Basic Science among Secondary Schools in Rivers State: Synergy of Parents ${ }^{e e}$ Educational Background, Socio- Economic Status and School Location. International Journal of Science and Research (IJSR).

Khalid, K., Ahmad, F.S., \& Norman, R. (2016).Information and Communication Technology in Learning Physics at Secondary School Level in Pakistan.Bulletin of Education and Research, Vol. 38, No. 2, 135-151.

Laode, A. (2019). Guru Fisika SMAN 2 Parigi.

Munir. (2012). Pembelajaran Jarak jauh Berbasis Teknologi Informasi dan Komunikasi, Bandung: Alfabeta. 
Murniati. (2019). Guru fisika SMAN 1 Parigi.

Mohammad, I., \& Novan, A.W. (2013).Psikologi Pendidikan Teori dan Aplikasi dalam Proses Pembelajaran. Jogjakarta: Arruz Media, 253-254.

Nini, S. (2011). Mengatasi Kesulitan Belajar Pada Anak, Jogjkarta: Javalitera, 12.

OECD.(2014). Perancis.

Yusri.(2015). Pengaruh Penggunaan Media Teknologi Informasi dan Komunikasi (TIK) dengan Prestasi Belajar Bahasa Inggris Peserta Didik Kelas $X$ di SMAN I Dekai Kabupaten Yahukimo.Jurnal Ilmiah ILKOM, Vol. 8 No. $1,51$.

Zahra, H., \& Ali, H. (2014).The Effect Of Information Technology in Teaching Physics Courses. The Eurasia Proceedings of Educational \& Social Sciences (EPESS).Volume 1, 391396.

Zakir, S. 2007. Usaha Guru Dalam Mengatasi Anak Yang Bermasalah Dalam Belajar. 